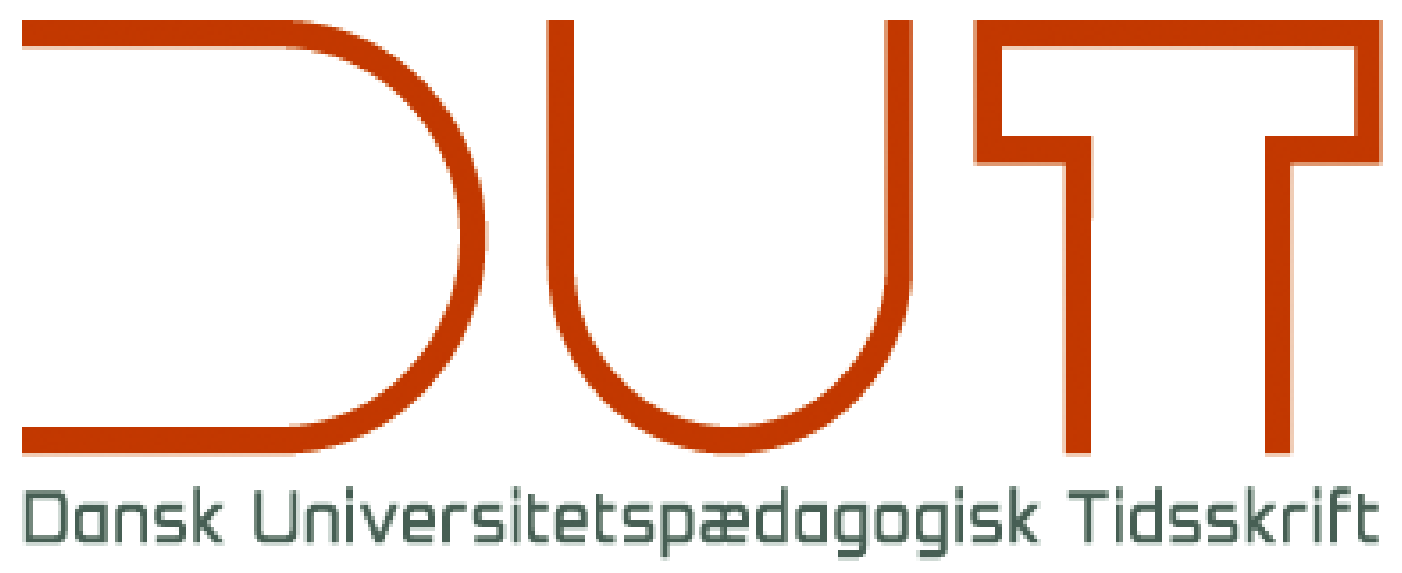

Tema

Fra data til beslutninger

Årgang 14 nr. 26 / 2019

Titel

Kan videregående uddannelser mindske frafald ved hjælp af læringsteknologi? Et systematisk review

Forfattere

Sidetal

Maria Hvid Stenalt, Berit Lassesen, Dorte Sidelmann Rossen, Anna Bager-Elsborg

$82-102$

Udgivet af

Dansk Universitetspædagogisk Netværk, DUN

URL

> http://dun-net.dk/

Betingelser for brug af denne artikel

(C) Copyright
Denne artikel er omfattet af ophavsretsloven, og der må citeres fra den. Følgende betingelser skal dog være opfyldt:

- Citatet skal være i overensstemmelse med "god skik"

- Der må kun citeres „i det omfang, som betinges af formålet“

- Ophavsmanden til teksten skal krediteres, og kilden skal angives ift. ovenstående bibliografiske oplysninger.

DUT og artiklens forfatter 


\title{
Kan videregående uddannelser mindske frafald ved hjælp af læringsteknologi? Et systematisk review
}

\author{
Maria Hvid Stenalta, ${ }^{a}$, Berit Lassesen ${ }^{b}$, Dorte Sidelmann Rossenc ${ }^{c}$ Anna Bager-Elsborg ${ }^{\mathrm{d}}$ \\ a,b,c,dCenter for Undervisning og Læring, Aarhus Universitet
}

Faglig artikel, fagfællebedømt

\begin{abstract}
Denne artikel undersøger to centrale forhold for uddannelseskvalitet, hhv. frafald og læringsteknologi, hvis sammenhæng danske universiteter i stigende grad interesserer sig for. Formålet med undersøgelsen er at afdække, hvorvidt brugen af læringsteknologi kan bidrage til at reducere de studerendes frafald på videregående uddannelser, og under hvilke betingelser? Det sker ved hjælp af et systematisk review af nyere international, peer-reviewed litteratur, der beskriver sammenhængen mellem frafald og læringsteknologi på de videregående uddannelser. Ud af 1.483 fremsøgte referencer levede 10 studier op til kriterierne for inklusion. Resultaterne af denne undersøgelse indikerer, at man ved hjælp af læringsteknologi og en forholdsvis lille indsats i nogle sammenhænge kan fastholde og motivere de studerende til at engagere sig i faget. Samtidig finder vi også, at det ikke er muligt at løse frafaldsproblematikker ved blot at tilføje mere læringsteknologi i uddannelserne.
\end{abstract}

\section{Introduktion}

Mindskelse af frafald blandt studerende er et centralt universitetspolitisk mål (f.eks. Uddannelses- og Forskningsministeriet, 2018). Udover at den enkelte studerende kan opleve det at forlade en uddannelse som et nederlag, medfører frafald også et økonomisk tab for uddannelsesinstitutionerne, ligesom det udfordrer politiske målsætninger for befolkningens uddannelsesniveau og for studerendes samlede gennemførelsestid. Ifølge en undersøgelse fra Styrelsen for Forskning og Uddannelse er førsteårs-frafaldet på 16 \% på de videregående uddannelser for højt (Styrelsen for Forskning og Uddannelse, 2018). I forlængelse af dette kan man spørge, hvad uddannelsesinstitutionerne kan gøre for at mindske frafald.

Af styrelsens rapport fremgår det, at årsagerne til frafald skyldes flere forhold: Den væsentligste faktor omhandler uddannelsens vægtning af faglige aktiviteter, herunder det overvejende fokus på teoretiske fremfor praktiske aspekter (52 \%). Mange studerende angiver endvidere, at kravene til det faglige niveau er for høje (45\%). Derudover fremhæves oplevelsen af ensomhed på studiet (43 \%) og et ringe socialt miljø (38 \%) som forhold, der har betydning for de studerendes beslutning om at forlade uddannelsen. Andre studier af frafald har identificeret tilsvarende faktorer, der har betydning for frafald på de videregående uddannelser. Review-studier af frafald af hhv. Troelsen (Troelsen, 2011) og Ulriksen m.fl. (Ulriksen, Madsen, \& Holmegaard, 2010) peger på, at flere faktorer har betydning for frafald: studerendes sociale og kulturelle baggrund, social og faglig integration (f.eks. at kunne indfri kravene, og at faget opleves som interessant og relevant for den studerende selv), undervisningen og den

\footnotetext{
${ }^{1}$ Kontakt: mstenalt@au.dk
} 
uformelle kontakt til undervisere og andet universitetspersonale samt det opnåede karaktergennemsnit fra den adgangsgivende uddannelse (højere karakter reducerer risikoen for frafald). Studierne indikerer også, at årsager til frafald både kan ligge forud for studiestart, uden for uddannelsen og i selve uddannelsen. Ikke desto mindre er der i undersøgelser af frafald en tendens til at fokusere på de faktorer, der ligger forud for uddannelserne eller omkring studiestart, f.eks. de færdigheder som studerende har med sig, eller de forventninger som studerende har til uddannelsen (Ulriksen et al., 2010). Man kunne måske i stedet for ønske sig, at flere undersøgelser fokuserede på uddannelseskulturen på universitetet (Ulriksen et al., 2010).

På den baggrund er der god grund til at interessere sig for, om forløbet undervejs i uddannelserne (det der sker i undervisningen, strukturer omkring undervisningen og de studerendes læreprocesser i løbet af studiet) også kan indvirke på frafaldet.

I det følgende afsnit vil vi rette fokus mod en anden universitetspolitisk indsats, som nu også bliver koblet til frafald.

\section{Loringsteknologi og frafald}

I disse år investerer danske universiteter betydelige summer i læringsteknologi (Aarhus Universitet, 2018; Copenhagen Business School, 2017; Roskilde Universitet, 2017). Formålet med mange af disse tiltag er at bruge teknologien til at skabe fleksibilitet, variation og struktur i undervisningen og herigennem give mulighed for at fremme de studerendes faglighed. Brugen af læringsteknologi kobles også til fastholdelse af studerende. Aarhus Universitets strategiske rammekontrakt med ministeriet for 2018-2021 beskriver eksempelvis, hvordan nytænkning af underviseres didaktiske praksis koblet med teknologiens muligheder skal have bedre fastholdelse og faglig trivsel som ønskede sideeffekter (Aarhus Universitet \& Uddannelses- og Forskningsministeriet, 2018, p. 9). Tilsvarende beskriver Syddansk Universitet i deres strategiske rammekontrakt for 2018-2021, at målsætningen for at eksperimentere med pædagogik, didaktik og digitale teknologier på de enkelte uddannelser blandt andet er et højere læringsudbytte blandt studerende, mindre frafald og hurtigere gennemførelse (Syddansk Universitet \& Uddannelses- og Forskningsministeriet, 2018, p. 12).

Loeringsteknologi har i praksis været anvendt i mere end 15 år på de danske universiteter (Dørup, Gomme, Hansen, \& Heiberg, 2005). Ikke desto mindre kan det være svært at vide, hvad begrebet reelt dækker over. Tænketanken DEA beskriver læringsteknologi som en samlet betegnelse for "undervisningsredskaber- og tilgange, der hviler på en digital infrastruktur" (Jensen, Lindorf, Norn, \& Aller, 2015, s. 10). Med afsæt i den definition omfatter læringsteknologi et bredt spænd af selvstændige digitale teknologier såvel som samlinger af teknologier. Selvstændige teknologier kan være student response-systemer, blogs eller videokonferencesystemer, der kan anvendes til understøttelse af forskellige undervisningsaktiviteter. Læringsteknologi kan også beskrive learning management-systemer (LMS), der samler et helt universitets eller fakultets behov for flere læringsteknologier. Et LMS kan understøtte gennemførelse af kurser i forskellige leveringsformater, fordi det rummer flere funktioner, såsom kursusadministration, distribution af kursusmaterialer og online kursuskommunikation, -aktiviteter og -afleveringer. Kendetegnende for teknologierne er således også, at de anvendes i en sammenhæng, hvor de understøtter undervisnings- eller læringsaktiviteter. For at beskrive læringsteknologi i brug eller dens forankring i undervisningen anvender flere betegnelsen blended learning (Willis et al., 2017). Vi vil senere præcisere, hvordan blended learning skal forstås i nærværende undersøgelse. 
Inden for forskning såvel som i praksis er der stor interesse for effekten af læringsteknologi og scenarier for god brug af læringsteknologi. Via en gennemgang af empiriske studier, der angår undervisning og læring ved hjælp af teknologi, identificerer Price og Kirkwood (Price \& Kirkwood, 2011) en række temaer, som teknologi har vist sig velegnet til at understøtte. Temaerne er bl.a. (Price \& Kirkwood, 2011, s. 3-4):

- $\quad$ Mere fleksibilitet og let adgang til materialer

- Højere engagement blandt studerende

- $\quad$ Bedømmelse og feedback

- Udvikling af akademiske færdigheder

- $\quad$ Analyse af egen læring og personlig udvikling

- $\quad$ Samarbejde om indholdet og interaktion mellem medstuderende

- $\quad$ Kobling af teoretiske og praktiske aspekter

- $\quad$ Forberedelse af de studerende på arbejdslivet og eget liv

I nyere studier af studerendes brug af institutionaliseret læringsteknologi og studerendes oplevelse af fordelene herved, er det særligt strukturelle forhold, studerende vægter højt, herunder muligheden for at organisere deres uddannelse og kurser samt muligheden for at have adgang til undervisningsmateriale fra flere platforme (Caviglia, Dalsgaard, Davidsen \& Ryberg, 2018; Henderson, Selwyn \& Aston, 2017). Fra undervisningseksperimenter i en dansk universitetskontekst er der ikke desto mindre eksempler på, at læringsteknologi kan understøtte aktiviteter og læringsmål, der er relateret til studerendes faglige og sociale integration. Styrkelsen af den faglige integration kan blandt andet foregå ved at tilrettelægge undervisningsforløb, hvor studerende vha. online diskussionsfora diskuterer faglige problemstillinger (Møller, 2016), giver eller modtager feedback via et online peer-feedback-system (Bertel \& Bentzen, 2018) eller i fællesskab reflekterer over stoffet vha. blogs (Danbjørg, Clemensen, Hansen, Thrysøe \& Rothmann, 2018). Den sociale integration kan støttes ved at understøtte samarbejdet de studerende imellem, f.eks. i form af digitale kommunikationsaktiviteter (Davidsen \& Ryberg, 2016). De hidtidige erfaringer med læringsteknologi peger således på, at læringsteknologi kan inddrages i uddannelser og herigennem indvirke på nogle af de faktorer, der er fokus på i frafaldsteori (Tinto, 1975).

\section{Forskningsspørgsmål}

Der er os bekendt mangel på studier, der afdækker eller kan bekræfte, hvorvidt der er en sammenhængen mellem frafald og inddragelse af læringsteknologi i en universitetskontekst. Der er derfor god grund til at undersøge dette - ikke mindst på grund af en stadigt stigende interesse for læringsteknologi som middel til at øge kvaliteten af de studerendes læring på de videregående uddannelser og det fortsatte uddannelsespolitiske fokus på lavt frafald som mål for uddannelseskvalitet. Vi ønsker derfor at opnå en bedre forståelse af dette, såvel som en bedre forståelse af forhold, der kan bidrage til at reducere (eller øge) frafald i sammenhæng med brug af læringsteknologi.

Undersøgelsens overordnede mål er at besvare følgende spørgsmål:

- I I hilken grad kan brugen af læringsteknologi på videregående uddannelser bidrage til at mindske studerendes frafald, og under hvilke betingelser? 
Med afsæt i forskningsspørgsmålet har vi gennemført et systematisk review af empiriske studier, der undersøger frafald på de videregående uddannelser i sammenhænge, hvor læringsteknologi indgår. Vi har valgt denne metode, fordi vi vil afdække publiceret viden inden for området og integrere de forskelligartede studiers resultater inden for en samlet universitetspædagogisk ramme. Til gennemførelse af det systematiske review læner vi os op ad systematikken, som den ses beskrevet hos Littell et al. (Littell, Corcoran \& Pillai, 2008).

\section{Metode}

\section{Kriterier for studierne}

For at sikre, at studier, der indgår i reviewet: (1) angik universiteters traditionelle udbud af kurser og uddannelser (2) undersøgte studerendes frafald i et kursus eller på en uddannelse, hvor læringsteknologi anvendes og (3) undersøgte årsager til forskelle i frafald eller tilbyder forklaringer, der tager afsæt i kursets karakteristika (i modsætning til studerendes karakteristika) opstillede vi en række inklusions- og eksklusionskriterier (se Tabel 1).

Tabel 1. Inklusions- og eksklusionskriterier
Kriterier
Inklusion
Eksklusion

\begin{tabular}{l|l} 
Middel & $\begin{array}{l}\text { Studier, der angår brugen af } \\
\text { blended lear- } \\
\text { ning/læringsteknologi }\end{array}$ \\
Kontekst & $\begin{array}{l}\text { Studier, der angår traditionel } \\
\text { undervisning på videregående } \\
\text { uddannelser. dvs. bachelor-, } \\
\text { master- og kandidatuddannel- } \\
\text { ser }\end{array}$ \\
Mål & $\begin{array}{l}\text { Nyere studier (2007 - 2017) } \\
\text { Studier, der angår udbyttet af } \\
\text { teknologi i forhold til fastholdel- } \\
\text { se af studerende eller frafald } \\
\text { blandt studerende. }\end{array}$
\end{tabular}

Studier, der ikke angår brugen af blended learning/læringsteknologi

Studier, der ikke angår traditionel undervisning på videregående uddannelser. F.eks. massive open online courses (MOOCS), ph.d.-uddannelser og erhvervsskoler

Studier, der ligger før 2007

Studier, der ikke angår udbyttet af teknologi i forhold til fastholdelse af studerende eller studerendes frafald

Studier, der beskæftiger sig med fastholdelse af viden (genkalde/erindre) - frem for fastholdelse af studerende

Studier, der operationaliserer frafald.
Studier, der ikke operationaliserer frafald. 


\begin{tabular}{|c|c|c|}
\hline Publikationstype & $\begin{array}{l}\text { Peer-reviewed tidsskriftspubli- } \\
\text { kationer }\end{array}$ & $\begin{array}{l}\text { Ikke-peer-reviewed tidsskriftsstudier, } \\
\text { rapporter og lign. }\end{array}$ \\
\hline Sprog & Engelsk & Andre sprog end engelsk \\
\hline Analyseobjekt & $\begin{array}{l}\text { Studier, der angår variation på } \\
\text { kursus- eller uddannelsesniveau }\end{array}$ & $\begin{array}{l}\text { Studier, der ikke angår variation på } \\
\text { kursus- eller uddannelsesniveau, } \\
\text { f.eks., studier, der angår variation } \\
\text { vedr. studenterkarakteristika }\end{array}$ \\
\hline
\end{tabular}

Forskning i læringsteknologi er et relativt nyt felt, og udviklingen af læringsteknologier sker med stor hastighed. For at sikre en vis aktualitet i forhold til de anvendte teknologier i studierne opstillede vi en tidsbegrænsning på de medtagne studier. Således afgrænsede studierne sig til de sidste 10 år (publiceret mellem 2007 - 2017). Endvidere indgår udelukkende studier der er udgivet i engelsksprogede peer-reviewet tidskifter.

\section{Søgestrategi}

Søgestrategien bygger på undersøgelsens inklusions- og eksklusionskriterier. Identifikation af databaser såvel som søgestreng blev foretaget med afsæt i review guidelines inden for læringsteknologi (Henrie, Halverson \& Graham, 2015; Price \& Kirkwood, 2011) suppleret med en identifikation af databaser, der indeholder anerkendte universitetspædagogiske tidsskrifter. Derudover gennemførte vi prøvesøgninger for at sikre, at søgestrategien hverken blev for inkluderende (bred) eller for ekskluderende (smal). Søgestrategien indebar, at vi alene identificerede de studier, der i enten titel, abstract eller keywords beskrev, at de angik læringsteknologi, frafald og 'higher education'. Den endelige søgestrategi (illustreret i Tabel 2) blev anvendt i det omfang, det var muligt i de enkelte databaser.

Tabel 2. Søgetermer og -strategi

\begin{tabular}{|c|c|c|}
\hline Kategorier & Termer & Søgefelter \\
\hline Mål (frafald) & $\begin{array}{l}\text { retention OR attrition OR drop-out OR turnover } \\
\text { OR "at risk" }\end{array}$ & $\begin{array}{l}\text { Title or abstract Or } \\
\text { keywords/subject } \\
\text { terms }\end{array}$ \\
\hline $\begin{array}{l}\text { Middel (lærings- } \\
\text { teknologi) }\end{array}$ & $\begin{array}{l}\text { "blended learning" OR "computer assisted in- } \\
\text { struction" OR "computer managed instruction" } \\
\text { OR "courseware" OR "distance education" OR } \\
\text { "electronic learning" OR "integrated learning sys- } \\
\text { tems" OR "intelligent tutoring systems" OR } \\
\text { "online courses" OR "mobile learning" OR "virtual } \\
\text { classrooms" OR "web based Instruction" OR } \\
\text { "technology mediated" OR “online learning" OR } \\
\text { "Educational IT" OR "technology enhanced learn- } \\
\text { ing" OR "technology supported learning" OR "Hy- } \\
\text { brid learning" OR "technology" }\end{array}$ & $\begin{array}{l}\text { Title or abstract OR } \\
\text { subject term }\end{array}$ \\
\hline
\end{tabular}




\begin{tabular}{l|ll} 
Kontekst & "Higher education" & $\begin{array}{l}\text { Title or abstract OR } \\
\text { subject term }\end{array}$ \\
Årstal & $2007-2017$ & Search limitation \\
Publikationstype & Peer-reviewed journals & Search limitation \\
\hline
\end{tabular}

Følgende databaser blev anvendt til fremsøgning af studier:

- $\quad$ EBSCO HOST: ERIC (The Education Resource Information Center), CINAHL (Cumulative Index to Nursing and Allied Health Literature), British Education Index, Education Research Complete, Communication \& Mass Media Complete

- $\quad$ ProQuest: Australian Education Index, Education Database, PsycInfo

- Web of Science: Social Science Citation Index

- $\quad$ Scopus

\section{Screeningsprocessen}

Review-processen bestod af fem faser:

1. Databasescreening: Identifikation af større mængde referencer, der med afsæt i søgestrategien potentielt kan inkluderes i undersøgelsen.

2. Screening af referencer for relevans på abstract- og titel-niveau.

3. Screening af referencerne for relevans på fuldtekst-niveau.

4. Dataekstraktion: beskrivelse af de inkluderede studier (ophav og udvalgte karakteristika).

5. Kvalitetsbedømmelse: vurdering af studiernes troværdighed og kvalitet.

Alle screeninger og forhandlinger skete med afsæt i de opstillede inklusions- og eksklusionskriterier for nærværende undersøgelse. Fase 2 - 5 blev gennemført ved brug af reviewsystemet Covidence. Alle referencer blev vurderet af artiklens forfattere i teams. Uenighed om inddragelse/udelukkelse af en undersøgelse blev løst ved konsensus og diskussion med samtlige reviewere.

\section{Dataekstraktion og kvalitetsvurdering}

Følgende data blev udtrukket fra studierne i forbindelse med dataekstraktion: forfattere, publiceringsår, tidsskriftets impact-factor, karakteristika for studiet, herunder: geografi, uddannelsesniveau, undersøgelsesdesign, antallet af deltagere i undersøgelsen, anvendt mål for frafald, anvendt mål for læringsteknologi, sammenligningsgrundlaget i studiet og resultater.

Vi opstillede en tjekliste til vurdering af studiernes kvalitet. Skemaet blev udviklet iterativt med afsæt i guidelines for afrapportering af empiriske studier (Mager \& Nowak, 2012; SavinBaden \& Major, 2010; Tong, Sainsbury \& Craig, 2007) og testet inden endelig brug. Følgende foci blev operationaliseret i tjeklisten: forskningsspørgsmål, forskningsdesign, dataindsamling og dataanalyse, resultater, perspektivering og etiske overvejelser. Skemaet rummede derudover to spørgsmål, der var specifikke for denne undersøgelse og tilknyttet vurdering af 
studiernes metodebeskrivelse: 1 . "Er beskrivelsen af teknologien klart beskrevet og relevant i forhold til formålet med denne?" og 2. "Er målingen af frafald klart beskrevet og berettiget?" De enkelte punkter i tjeklisten kunne tildeles 0 (ikke til stede), 1 (i nogen grad) eller 2 (til stede) point. Artiklerne kunne maximalt opnå 40 point. Studier, der ikke opnåede (1) en samlet pointscore $\geq 30$ (ud af 40 mulige) og (2) mindst 8 point samlet i de spørgsmål, der angik studiets metodebeskrivelse, blev ekskluderet.

\section{Datasyntese}

Målet med datasyntesen var at samle resultaterne fra forskellige typer af forskning for herigennem at kunne beskrive forhold for brug af læringsteknologi, der hhv. påvirker eller ikke påvirker studerendes frafald. For at syntetisere de forskellige studier udviklede vi temaer med afsæt i vores dataekstraktion. Temaerne opstod ved at identificere studiernes operationalisering af læringsteknologi og de universitetspædagogiske eksperimenter i de studier, hvor læringsteknologi understøttede et sådant. Temaerne blev diskuteret blandt reviewerne og efterfølgende tilpasset.

\section{Resultater}

I det følgende sammenfattes resultaterne af de studier, der opnåede en score i kvalitetsvurderingen på minimum 30 point ud af 40 mulige og med mindst 8 point opnået i metodedelen. En typisk årsag til frasortering var en lav score i resultat- og/eller diskussionsdelen. Studier, som indgik i kvalitetsvurderingen, er beskrevet i Appendix A, hvori de endeligt inkluderede studier er markeret med en asterisk (*).

\section{Inkluderede studier}

Fremsøgning af studier blev gennemført i september 2017. Den indledende litteratursøgning i databaserne resulterede i 1.483 referencer, der blev importeret til Covidence (Tabel 3).

Tabel 3: Resultat af databasesøgning

\begin{tabular}{|c|c|c|c|}
\hline Dato & Søgestrategi & Database & Hits \\
\hline 25.9 .2017 & Søgning på title, abstract og subject terms & EBSCOhost & 774 \\
\hline do & Søgning på title, abstract og subject headings & Proquest & 399 \\
\hline do & Søgning på title og topic & $\begin{array}{l}\text { Web of sci- } \\
\text { ence }\end{array}$ & 78 \\
\hline do & Søgning på title, abstract, keywords & Scopus & 366 \\
\hline Hits i alt & & & 1617 \\
\hline $\begin{array}{l}\text { Antal referencer } \\
\text { importeret til Covi- } \\
\text { dence }\end{array}$ & $\begin{array}{l}\text { Baseret på databasernes egen reduktion af } \\
\text { hits (fjernelse af dubletter, forkerte publikati- } \\
\text { onstyper m.v.) }\end{array}$ & & 1483 \\
\hline
\end{tabular}


240 referencer blev vurderet på fuldtekstniveau, og ud af disse blev 10 referencer vurderet som kvalificerede til at indgå i den endelige analyse (Figur 1).

Figur 1. Flowdiagram
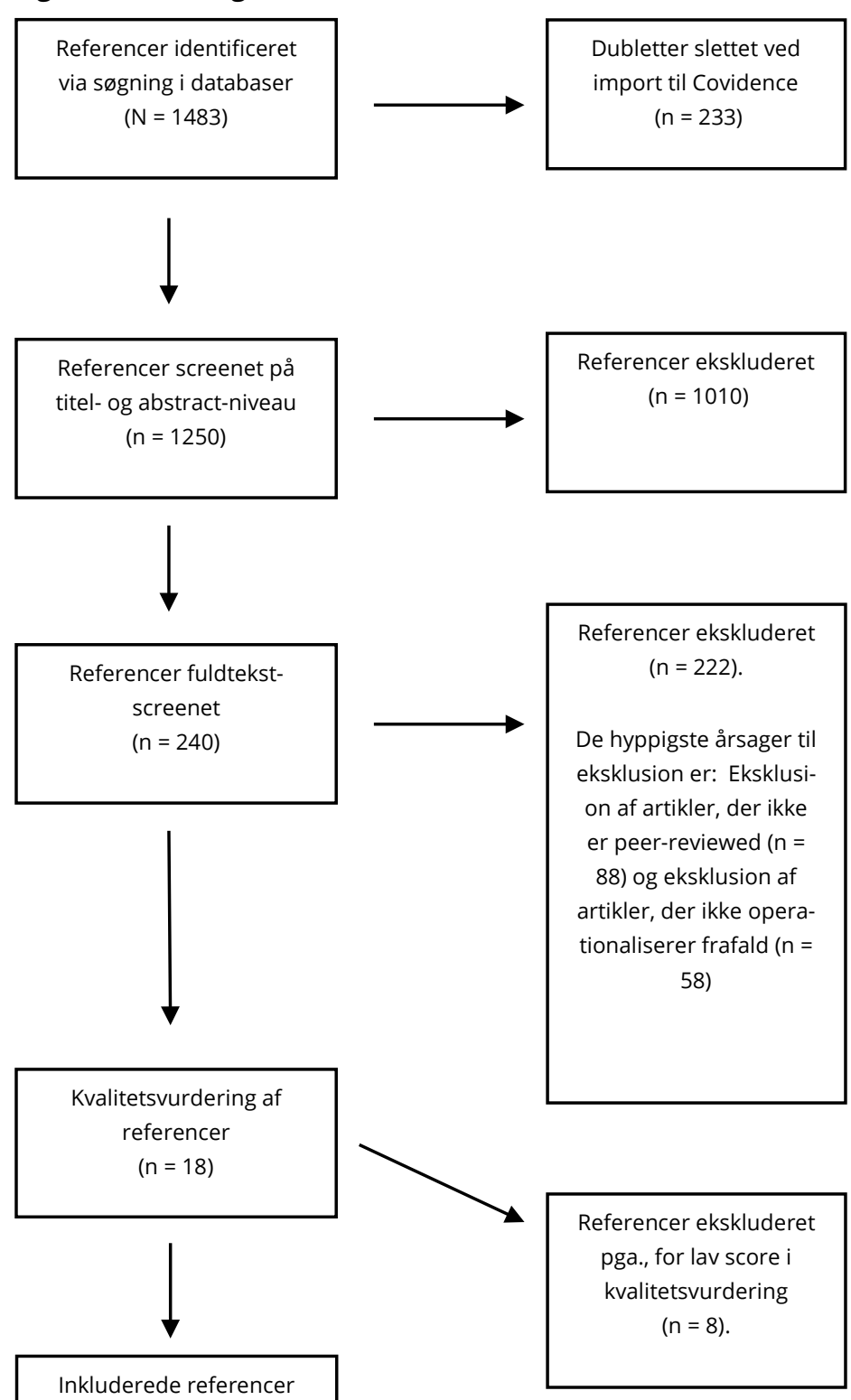

Inkluderede referencer $(n=10)$

De inkluderede studier dækker et bredt uddannelsesfagligt spektrum og stammer fortrinsvis fra amerikanske universiteter $(n=8)$. De resterende studier $(n=2)$ er gennemført i en hhv. engelsk og australsk kontekst. Størstedelen af studierne omhandler frafald blandt bachelorstuderende.

\section{Operationalisering af laeringsteknologi}

Vi fandt, at de inkluderede studier i særlig grad interesserer sig for campusbaseret undervisning $(n=6)$ og onlineundervisning $(n=6)$, dernæst blended learning-kurser $(n=4)$ og teknologiunderstøttet undervisning ( $n=3$ ) (se Tabel 4). Studierne er heterogene i forhold til deres operationalisering af læringsteknologi og undersøgelsesdesign. Således undersøges effekten af anvendelse af læringsteknologi inden for (a) et kursus i et format, (b) et kursus i forskellige 
formater og (c) forskellige kurser i forskellige formater. Tabel 4 beskriver reviewets definition af leveringsformater og fordelingen af studierne i forhold til de leveringsformater, der indgår i undersøgelserne. På grund af reviewets overvægt af amerikanske studier er definitionerne perspektiveret til en amerikansk praksis (Online Learning Consortium, 2015), hvor leveringsformater defineres ud fra omfanget af kursusaktiviteter, der foregår online (versus på campus).

Tabel 4. Leveringsformater, der indgår i reviewet (bearbejdet efter Online Learning Consortium, 2015)

\begin{tabular}{|c|c|c|c|}
\hline $\begin{array}{l}\text { Leverings- } \\
\text { format }\end{array}$ & Beskrivelse & $\begin{array}{l}\text { Forkortelse i } \\
\text { reviewet }\end{array}$ & $\begin{array}{l}\text { Studier, der behandler } \\
\text { formatet* }\end{array}$ \\
\hline $\begin{array}{l}\text { Campusbase- } \\
\text { ret undervis- } \\
\text { ning }\end{array}$ & $\begin{array}{l}\text { Undervisningen er organiseret } \\
\text { som face-to-face-møder uden } \\
\text { brug af læringsteknologi, og hvor } \\
\text { læringsteknologi primært under- } \\
\text { støtter mere administrative opga- } \\
\text { ver. }\end{array}$ & $\mathrm{F} 2 \mathrm{~F}$ & $\begin{array}{l}\text { Ashby, Sadera \& McNary } \\
\text { (2011); Hughes (2007); } \\
\text { Liu \& Stengel (2011); } \\
\text { Powers, Brooks, Galazyn } \\
\text { \& Donnelly (2015); } \\
\text { Wladis, Conway \& } \\
\text { Hachey (2017); Xu \& } \\
\text { Jaggars (2011) }\end{array}$ \\
\hline $\begin{array}{l}\text { Teknologi- } \\
\text { støttet un- } \\
\text { dervisning }\end{array}$ & $\begin{array}{l}\text { Online kursusaktiviteter supplerer } \\
\text { campusbaseret undervisning } \\
\text { uden at reducere antallet af face- } \\
\text { to-face-møder. }\end{array}$ & TEK & $\begin{array}{l}\text { Garratt-Reed, Roberts \& } \\
\text { Heritage (2016); Griff \& } \\
\text { Matter (2013); Liu \& } \\
\text { Stengel (2011) }\end{array}$ \\
\hline $\begin{array}{l}\text { Blended (eller } \\
\text { hybrid) lear- } \\
\text { ning }\end{array}$ & $\begin{array}{l}\text { Online kursusaktiviteter er kom- } \\
\text { bineret med campusbaseret un- } \\
\text { dervisning, og de erstatter en } \\
\text { væsentlig del af face-to-face- } \\
\text { møderne. I amerikansk kontekst } \\
\text { har man hidtil typisk defineret et } \\
\text { kursus med op til } 79 \% \text { online } \\
\text { kursusaktiviteter som blended } \\
\text { learning. }\end{array}$ & $\mathrm{BL}$ & $\begin{array}{l}\text { Ashby et al. (2011); } \\
\text { Hughes (2007); Powers } \\
\text { et al. (2015); Wladis et al. } \\
\text { (2017) }\end{array}$ \\
\hline $\begin{array}{l}\text { Onlineunder- } \\
\text { visning }\end{array}$ & $\begin{array}{l}\text { Størstedelen eller al undervisning } \\
\text { foregår online. I amerikansk kon- } \\
\text { tekst defineres et kursus typisk } \\
\text { som online, hvis } 80 \text { \% eller der- } \\
\text { over af undervisningen foregår } \\
\text { online. }\end{array}$ & $\mathrm{O}$ & $\begin{array}{l}\text { Ashby et al. (2011); } \\
\text { Garratt-Reed et al. } \\
\text { (2016); Pittenger \& } \\
\text { Doering (2010); Robb \& } \\
\text { Sutton (2014); Wladis et } \\
\text { al. (2017); Xu and Jaggars } \\
\text { (2011) }\end{array}$ \\
\hline
\end{tabular}


*Et studie kan behandle flere formater. Identifikation af de leveringsformater, der indgår i studierne, bygger dels på studiernes egen beskrivelse heraf og dels på vores vurdering af det beskrevne leveringsformat jf. vores definition.

\section{Studiernes definition af frafald}

Definitionen af frafald varierer i de inkluderede studier. Størsteparten af studierne unders $\varnothing$ ger frafald på kursusniveau. Frafald på kursusniveau defineres bl.a. i forhold til (1) andelen af studerende der gennemfører hele kurser eller moduler i et kursus (f.eks. Liu \& Stengel, 2011), (2) andelen af studerende der deltager i eksamen (f.eks. Inkelaar \& Simpson, 2015), (3) de studerendes faglige præstationer, f.eks. andelen af studerende der opnår karakteren lavere end " $C$ " (Wladis et al., 2017; Xu \& Jaggars, 2011) eller (4) andelen af studerende der ikke opnår $70 \%$ rigtige eksamenssvar (f.eks. Ashby et al., 2011).

\section{Syntese af inkluderede studier}

Vi identificerede fire temaer i de inkluderede studier: Hhv. studier, der undersøger: (1) de leveringsformater der er opstået i tilknytning til brug af læringsteknologi, (2) læringsteknologi, der faciliterer aktiverende F2F-undervisning, (3) læringsteknologi, der anvendes til adaptiv og automatiseret instruktion og (4) tilrettelæggelse af teknologiunderstøttede forløb med fokus på motiverende kommunikation og kursusdesign (se Tabel 5).

Tabel 5: Temaer og studiernes resultater

\begin{tabular}{|c|c|c|c|}
\hline Tema & Forfatter & Studiet & Resultat \\
\hline \multirow[t]{4}{*}{ Leveringsformater } & $\begin{array}{l}\text { Ashby et al. } \\
(2011)\end{array}$ & $\begin{array}{l}\text { Sammenligner tre leveringsforma- } \\
\text { ter F2F/BL/O inden for samme } \\
\text { kursus i relation til antal stude- } \\
\text { rende, der består eksamen. }\end{array}$ & $\begin{array}{l}\text { Der ses ingen for- } \\
\text { skelle }\end{array}$ \\
\hline & $\begin{array}{l}\text { Garratt- } \\
\text { Reed et al. } \\
(2016)\end{array}$ & $\begin{array}{l}\text { Sammenligner et O-forløb med et } \\
\text { TEK-forløb i relation til antallet af } \\
\text { studerende, der består eksamen. }\end{array}$ & TEK $>0$ \\
\hline & $\begin{array}{l}\text { Xu \& Jaggars } \\
\text { (2011) }\end{array}$ & $\begin{array}{l}\text { Sammenligner frafald mellem to } \\
\text { formater F2F/O på to fag. }\end{array}$ & $\mathrm{F} 2 \mathrm{~F}<\mathrm{O}$ \\
\hline & $\begin{array}{l}\text { Wladis et al. } \\
\text { (2017) }\end{array}$ & $\begin{array}{l}\text { Sammenligner } \\
\text { A: Overordnet forskelle i frafald i } \\
\text { F2F over for O/BL. } \\
\text { Underordnet } \\
\text { B: Valgfrie/Obligatoriske } \\
\text { C: Lower/upper level kurser }\end{array}$ & $\begin{array}{l}\text { A: F2F }<O \text { og BL } \\
B: F 2 F<O \text { og } B L \\
C: O<F 2 F\end{array}$ \\
\hline $\begin{array}{l}\text { Aktiverende F2F- } \\
\text { undervisning }\end{array}$ & $\begin{array}{l}\text { Liu \& } \\
\text { Stengel } \\
(2011)\end{array}$ & $\begin{array}{l}\text { Sammenligner frafald på under- } \\
\text { visningsforløb, der hhv. inddrager } \\
\text { (TEK) eller ikke inddrager clickers } \\
\text { (F2F). }\end{array}$ & TEK $<$ F2F \\
\hline
\end{tabular}




\begin{tabular}{|c|c|c|c|}
\hline \multirow[t]{2}{*}{$\begin{array}{l}\text { Adaptiv og auto- } \\
\text { matiseret instruk- } \\
\text { tion }\end{array}$} & $\begin{array}{l}\text { Griff \& } \\
\text { Matter } \\
(2013)\end{array}$ & $\begin{array}{l}\text { Sammenligner forskelle i frafald } \\
\text { og faglig præstation mellem to } \\
\text { formater (adaptivt, automatiseret } \\
\text { instruktion vs. underviserudvalgte } \\
\text { spørgsmål fra online spørgsmåls- } \\
\text { bank). }\end{array}$ & $\begin{array}{l}\text { Ingen signifikante } \\
\text { forskelle. }\end{array}$ \\
\hline & $\begin{array}{l}\text { Powers et } \\
\text { al. (2015) }\end{array}$ & $\begin{array}{l}\text { Sammenligner frafald mellem to } \\
\text { formater: F2F vs. BL (med brug af } \\
\text { adaptivt, automatiseret instrukti- } \\
\text { on) }\end{array}$ & $\begin{array}{l}\text { Ingen signifikante } \\
\text { forskelle. }\end{array}$ \\
\hline \multirow[t]{3}{*}{$\begin{array}{l}\text { Motiverende } \\
\text { kommunikation } \\
\text { og kursusdesign }\end{array}$} & $\begin{array}{l}\text { Pittenger \& } \\
\text { Doering } \\
(2010)\end{array}$ & $\begin{array}{l}\text { Undersøger, hvorvidt e-mails til } \\
\text { stud. med opfordring til aktiv del- } \\
\text { tagelse, læringsaktiviteter med } \\
\text { fokus på aktiv læring og fleksibili- } \\
\text { tet i forhold til gennemførelse af } \\
\text { opgaver på et O-forløb kan bidra- } \\
\text { ge til at reducere frafald. }\end{array}$ & $\begin{array}{l}\geq 95 \% \text { studerende } \\
\text { gennemfører kur- } \\
\text { set. } \\
\text { Det er ikke muligt } \\
\text { at gennemskue, } \\
\text { om resultatet ale- } \\
\text { ne kan henføres til } \\
\text { de kommunikative } \\
\text { aspekter. }\end{array}$ \\
\hline & $\begin{array}{l}\text { Robb \& } \\
\text { Sutton } \\
(2014)\end{array}$ & $\begin{array}{l}\text { Sammenligner frafald mellem to } \\
\text { grupper af studerende på et O- } \\
\text { forløb: } \\
\text { Gruppe } 1 \text { modtager fem e-mails } \\
\text { henover semestret (ikke persona- } \\
\text { liserede) med rådgivning om pro- } \\
\text { gression, påmindelser om at gen- } \\
\text { nemse feedback, anerkendelse af } \\
\text { arbejdsindsats og opfordring til at } \\
\text { gennemføre kurset. } \\
\text { Gruppe 2: Modtager ikke e-mails. }\end{array}$ & $\begin{array}{l}\text { Frafald gruppe } 1< \\
\text { gruppe } 2 .\end{array}$ \\
\hline & $\begin{array}{l}\text { Hughes } \\
\text { (2007) }\end{array}$ & $\begin{array}{l}\text { Sammenligner frafald mellem to } \\
\text { BL-kurser, hvor der på det ene } \\
\text { kursus ydes en særlig proaktiv } \\
\text { støtte til frafaldstruede studeren- } \\
\text { de i form af ekstra vejledning og } \\
\text { opmuntrende kommunikation. }\end{array}$ & $\begin{array}{l}\text { Frafaldet er lavere } \\
\text { på det kursus, der } \\
\text { indeholder lø- } \\
\text { bende support (6 } \\
\% \text { vs. } 17 \% \text { ). }\end{array}$ \\
\hline
\end{tabular}




\section{Tema: Leveringsformater}

Med introduktionen af nye formater for levering af kurser, såsom rene onlinekurser, er der opstået en interesse for at undersøge virkningen af de nye leveringsformater over for det traditionelle campusbaserede leveringsformat (Means, Toyama, Murphy, Bakia \& Jones, 2010). I dette review indgår fire studier, der undersøger hvorvidt leveringsformatet indvirker på frafald.

Ashby et al. (2011) finder ingen signifikante forskelle på andelen af community collegestuderende, der inden for hvert af studiets tre undersøgte leveringsformater består kurset ( $\mathrm{F} 2 \mathrm{~F}=59 \% ; \mathrm{BL}=48 \% ; \mathrm{O}=65 \%$ ). Derimod finder man, at en større andel F2F-studerende gennemfører kursusforløbet, der leder op til den afsluttende eksamen (F2F=93 \%; BL=70 \%; O=76 \%). Forfatterne påpeger, at den lavere kursusgennemførelse for hhv. BL- og O-studerende kan skyldes, at formaterne ikke appellerer til de studerende, men også at de faglige forudsætninger blandt studerende på community colleges generelt er lidt lavere end blandt studerende på øvrige colleges eller universiteter.

Garratt-Reed og kolleger (2016) finder, at forskellen på antallet af studerende, der bestod et TEK-forløb, var signifikant højere (96\%) end de, der bestod et O-forløb (91\%) ( $p=0.018, d=$ 0.47). Ved en nærmere undersøgelse af eksamensresultatet finder de, at resultatet særligt skyldes, at de, der deltog i TEK-forløbet, opnåede signifikant bedre resultater i forbindelse med gruppeopgaver end de, der deltog i O-forløbet.

I Xu og Jaggars (2011) undersøgelse sammenlignes et F2F-format med et O-format i to introduktionsforløb (hhv. engelsk og matematik) ved brug af registerdata fra mere end 20 forskellige uddannelsesinstitutioner med lokale udgaver af de specifikke undervisningsforløb. Forskerne finder, at frafaldet er signifikant højere blandt studerende, der deltager i rene online forløb. På engelskkurset udgør frafaldet blandt O-studerende $19 \% \bmod 10 \%$ blandt F2Fstuderende. På matematik er frafaldet på 25 \% blandt O-studerende mod 12 \% blandt F2Fstuderende. Forfatterne argumenterer for, at denne forskel først og fremmest skyldes forskelle i studenterforudsætninger/karakteristika fremfor leveringsformatet.

Wladis et al. (2017) undersøger ligeledes betydningen af leveringsformatet (O/BL/F2F) for at nuancere, hvorvidt et O- eller BL-format er mere velegnet til bestemte kursustyper end et F2F-format. Omvendt, undersøger forskerne tillige betydningen af, om kurset er valgfrit, 'distributional' eller obligatorisk, kursets sværhedsgrad og den faglige disciplin (STEM vs. ikkeSTEM). Samme kursus udbydes i forskellige formater (O/BL/F2F) i samme semester af samme underviser og gentages i en længere årrække (2004-2010). Resultaterne viser for det første, at der i perioden generelt er en bedre fastholdelse af de studerende i F2F-formatet (65,3\%) sammenlignet med O/BL-formatet (58,6\%), men at der er betydelige nuancer. På valgfrie kurser ses et signifikant højere frafald i O/BL-formatet sammenlignet med F2F-formatet over for de samme formater i obligatoriske kurser. Til gengæld gennemfører de studerende i højere grad et Lower Level-kursus online $(49,9 \%)$ end F2F $(42,2 \%)$, mens billedet er omvendt ved Upper Level-kurser. Generelt er den gennemsnitlige kursusgennemførelse signifikant bedre for Upper Level-kurser i forhold til Lower Level-kurser i både F2F-format og O/BLformat. 


\section{Tema: Aktiverende F2F-undervisning}

Gennem de seneste årtier har der været øget fokus på at udvikle universitetsundervisningen fra transmission af viden til mere aktiverende undervisning (Biggs \& Tang, 2011). Ud af de 10 studier, der indgår i syntesen, undersøger ét, hvorvidt undervisning, der fokuserer på at aktivere de studerende i timerne, kan bidrage til at reducere frafald.

Liu \& Stengel (2011) sammenligner frafald i kurser, der hhv. anvender (TEK)/ikke anvender clickers (F2F) til at løse multiple choice-opgaver præsenteret af underviseren på campus. I TEK-forløbet drøftes løsninger med underviseren. Den traditionelle F2F-udgave af kurserne består af forelæsninger ved samme underviser og tilsvarende øvelser i timerne - blot uden afrapportering og feedback. Liu og Stengel finder, at frafaldet er lavere i TEK-forløbet sammenlignet med F2F-formatet. Desuden opnår de studerende bedre resultater i de løbende tests fraset et enkelt eksempel, hvor studerende, der deltager i F2F-formatet, opnår bedre resultater. Forfatterne anfører, at årsagen til dette kan skyldes, at nogle af emnerne i den pågældende test er mere komplekse og muligvis ikke egner sig til det anvendte multiple choice-format.

\section{Tema: Adaptiv og automatiseret instruktion}

Automatiseret instruktion eller adaptive læringssystemer vurderer og guider studerende igennem typisk mindre dele af et fagområde online (Willis et al., 2018, s. 50). Med afsæt i den studerendes besvarelser på opgaver tilpasses instruktionen den studerendes niveau, og herved kan den studerende opleve at få et individualiseret og 'just-in-time'-læringsforløb. Hensigten med denne type instruktion er typisk ikke at erstatte underviseren, men at tilbyde studerende et supplement til den eksisterende undervisning. Materialet er ofte udviklet af en ekstern part som f.eks. et forlag, der i forvejen udgiver centrale lærebøger inden for fagområdet. I dette review angår to af de inkluderede studier automatiseret instruktion.

I Griff \& Matters (2013) studie med deltagelse af 6 institutioner undersøges effekten af et adaptivt læringssystem udviklet til bachelorstuderende inden for anatomi eller fysiologi. Indholdet, som de studerende skal arbejde med, udvælges af instruktorer. Kontrolgruppen får spørgsmål fra en spørgsmålsbank, ligeledes udvalgt af en instruktor. Resultaterne viser, at begge grupper af studerende forøger deres viden, og der ses ingen signifikant forskel på de to grupper i forhold til præstation eller frafald. Derimod finder forskerne, at der på to af de involverede institutioner er en forskel på eksperiment- og kontrolgruppen. Undersøgelsen kan ikke afdække årsagen til denne forskel. Forfatterne konkluderer, at nærværende studie ikke understøtter andre studiers fund af effekten af adaptive materialer, og de vurderer, at det i dette tilfælde muligvis kan skyldes instruktorens indflydelse.

I studiet af Powers et al. (2016) sammenlignes frafald for to grupper af studerende, der hhv. deltager $\mathrm{i}$ et F2F-forløb og $\mathrm{i}$ et BL-forløb, hvori der indgår et adaptivt læringselement (MyPsychLab). De to grupper gennemgår det samme faglige indhold, og undervisningsforløbene afvikles parallelt. Resultaterne af denne undersøgelse viser ingen forskelle i frafald mellem de to grupper. Frafaldsprocenten udgjorde 16,8 \% for BL-studerende og 14,8 \% for F2Fstuderende. Forfatterne oplyser endvidere, at ingen af de studerende, der deltog i BLforløbet, og som faldt fra, havde besøgt MyPsychLab. Selvom undersøgelsen ikke kan udsige noget om de studerendes holdning til onlineundervisningselementerne, indikerer forskerne alligevel, at forskellen kan være et udtryk for, at denne gruppe ikke var motiverede af mulighederne og kravene til online selvstudie. De konkluderer derpå, at studerendes motivation $\mathrm{i}$ 
forhold til at arbejde med online læringsmateriale kan udfordre antagelsen om, at adaptive undervisningsformater kan erstatte traditionel undervisning.

\section{Tema: Motiverende kommunikation og kursusdesign}

Selvom læring i høj grad afhænger af studerendes viden og evnen til at anvende denne, har forskning også vist, at motivation og interesse fremmer de studerendes læreprocesser (Bandura, 1993). Tre af de inkluderede studier undersøger effekten af motiverende elementer i undervisningen. To af disse studier omhandler O-forløb tilrettelagt som selvstudie, mens det tredje studie omhandler et BL-forløb.

Robb \& Sutton (2014) sammenligner to grupper i et O-forløb, hvoraf en gruppe af studerende modtager fem motiverende og ikke personaliserede e-mails. Disse indeholder blandt andet: rådgivning om progression, påmindelser om at gennemse feedback, anerkendelse af arbejdsindsats og opfordring til at gennemføre kurset. Den anden gruppe modtager ingen mails, men har adgang til de samme informationer på en kursusside. Frafaldet blandt de studerende i gruppen, der modtager e-mails, er lavere sammenlignet med gruppen, der ikke modtager e-mails.

Pittenger \& Doering (2010) undersøger studerendes oplevelse af et O-forløb, der er kendetegnet ved en høj gennemførelsesprocent ( $\geq 95 \%$.). Deres komparative analyse af fire Okurser indikerer, at en velorganiseret kursusstruktur, ugentlige e-mails med forslag til deltagelse i kursets aktiviteter og opgaver, læringsaktiviteter med fokus på aktiv læring og fleksibilitet i forhold til gennemførelse af opgaver kan bidrage til at reducere frafald. Blandt andet rapporterer de studerende, at designet af de fire kurser indeholder en undervisningsmæssig stilladsering, der fanger deres opmærksomhed, opleves som relevant for dem og giver dem tillid til, at de kan gennemføre kurset. Overordnet set resulterer det i en høj grad af tilfredshed. Det kursus, som de studerende giver den laveste score mht. motiverende elementer, adskiller sig fra de øvrige ved ikke at have en tekstbog og ved udelukkende at bestå af online læringsmaterialer såsom audiopræsentationer og slide-handouts. Derudover kræver dette kursus deltagelse i fire eksaminer undervejs, i modsætning til de øvrige kurser, der kun kræver deltagelse i den afsluttende eksamen. Forfatterne overvejer, hvorvidt studerende demotiveres af de mange afprøvninger, der trækker på strukturer fra traditionelle F2F-kurser.

I Hughes' (2007) undersøgelse er der fokus på et BL-kursus, hvor 30 \% af forelæsningerne er omlagt til online aktiviteter og online vejledning til frafaldstruede studerende. Underviseren følger de studerendes adfærd på en kursusside og giver særlig vejledning (af administrativ, teknisk, motiverende eller faglig karakter) til de studerende, der er mindre aktive. Hughes finder, at kombinationen af proaktiv hjælp og opmuntrende kommunikation øger antallet af studerende, der gennemfører kurset, sammenlignet med en tidligere version af BL-forløbet uden support. Frafaldet er hhv. på $6 \%$ og $17 \%$ i forløbet med support mod $25 \%$ i forløbet uden særlig support til frafaldstruede studerende. Data fra det samme kursus i et F2F-format viser et frafald på 25-55 \% på disse kurser. Hughes konkluderer deraf, at et veltilrettelagt BLforløb med online aktiviteter og online vejledning til frafaldstruede studerende har en positiv betydning i forhold til at øge andelen af studerende, der gennemfører kursusforløbet.

\section{Opsamling}

Vi stillede spørgsmålet: I hvilken grad kan læringsteknologi bidrage til at reducere frafald på de videregående uddannelser? Vi har i det foregående givet et overblik over et udsnit af nyere empirisk forskning, der undersøger dette. Som et væsentligt træk fandt vi, at frafald ikke er 
entydigt operationaliseret i studierne. Frafald varierer eksempelvis fra manglende deltagelse eller beståelse af kursusmoduler til bestået/ikke bestået eksamen. Derudover fandt vi, at studierne undersøger inddragelsen af læringsteknologi forskelligt: (1) som leveringsformat og (2) med afsæt i undervisningseksperimenter eller kursusdesigns, der på forskellig vis inddrager læringsteknologi.

Den første gruppe, der undersøger leveringsformater, består af fire studier. Heraf finder et studie ingen forskelle mellem de undersøgte leveringsformater. De tre øvrige studier giver samlet set ikke et entydigt billede af betydningen af leveringsformatet på frafald. Resultaterne af studierne indikerer, at kurser med ingen eller nogle online kursusaktiviteter (F2F eller TEK) har lavere frafald blandt studerende i sammenligning med kurser med høj forekomst af online kursusaktiviteter (BL eller O). Det fremgår dog ikke klart af studierne, hvilke udfordringer som studerende eller undervisere oplever ved de forskellige leveringsformater.

I den anden gruppe indgår seks studier, der angår brugen af læringsteknologi forankret i en undervisningspraksis. Fokus i studierne er således ikke på betydningen af læringsteknologi alene, men også på koblingen af pædagogiske valg med læringsteknologi. Fire studier finder en positiv sammenhæng mellem lavere frafald og tiltag i undervisningen, der gennemføres vha. læringsteknologi. To studier finder ingen effekt af teknologiinddragelse.

Det næste spørgsmål er: Under hvilke betingelser kan brugen af læringsteknologi på videregående uddannelser bidrage til at mindske studerendes frafald? Det spørgsmål besvares i højere grad i de studier, der beskriver et pædagogisk rationale og de kontekstuelle forhold for brugen af læringsteknologi. Under afsnittet om aktiverende undervisning så vi, at undervisning med brug af et digitalt afstemningsværktøj til at aktivere studerende kan bidrage positivt til reducering af frafald (Liu \& Stengel, 2011). I det konkrete tilfælde fandt man, at flere af de studerende, der anvendte afstemningsværktøjet i undervisningen, gennemførte kursusmodulet sammenlignet med de studerende, der ikke anvendte afstemningsværktøjet. Idéen bag digitale afstemningsværktøjer er at give studerende mulighed for at reflektere over fagets indhold, samtidig med at de får feedback på deres niveau og forståelse af emnet (Dyrberg, 2014). Feedback vurderes at være en betydningsfuld faktor - særligt i forbindelse med forelæsningsformatet, der ofte indebærer mindre interaktion, og hvor det kan være vanskeligt for forelæseren at fornemme, om de studerende forstår det forklarede (Dyrberg, 2014). I afsnittet om adaptiv og automatiseret instruktion gennemgik vi to studier, der undersøger effekten af automatiseret instruktion eller adaptive online læringssystemer, der tilbyder studerende individualiseret instruktion (Griff \& Matter, 2013; Powers et al., 2015). Begge studier finder ingen effekt af brugen af adaptiv instruktion, men der er forskelle i de to studier, som er værd at fremhæve. I det ene studie indgik adaptivt materiale som et supplement, og i det andet studie erstattede det F2F-undervisningstid, hvilket i dette tilfælde også indebar reduceret mulighed for social og faglig interaktion mellem medstuderende og undervisere. I sidstnævnte studie (Powers et al., 2015) konkluderede man, at det er nødvendigt at understøtte de studerendes arbejde med materialet og i højere grad at skabe en bedre integration mellem dette materiale og resten af undervisningen for at højne læringsudbyttet og de studerendes motivation. Det peger på betydningen af tilrettelæggelse af undervisningsaktiviteter i undervisningen og betydningen af at sammentænke dette med studerendes nuværende niveau for viden og krav til eksamen. Sidstnævnte blev netop fremhævet som en medierende faktor i det første studie. I syntesen gennemgik vi endvidere tre studier, der peger på, at brugen af motiverende kommunikation og motiverende kursusdesign kan bidrage til at reducere frafald. Dette kan f.eks. være i form af personlige e-mails til de studerende (Robb \& Sutton, 
2014), kursusplanlægning med fokus på motiverende elementer (Pittenger \& Doering, 2010) eller særlig monitorering af og støtte til frafaldstruede studerende (Hughes, 2007).

Samlet set indikerer disse studier, at underviseren spiller en central rolle i forhold til at tilrettelægge kurser og aktiviteter, der ved hjælp af læringsteknologi motiverer og aktiverer studerende.

\section{Diskussion og forslag til videre forskning}

I reviewet har vi gennemgået studier, der undersøger, hvorvidt teknologi i undervisningen kan bidrage til at reducere frafald. Resultaterne viser, at det ikke er muligt at løse frafaldsproblematikker ved blot at tilføje mere læringsteknologi. Ydermere viser de, at der kan være en positiv sammenhæng mellem frafald og teknologiunderstøttet undervisning. Der, hvor vi ser positive fund, er særligt i de studier, hvori der indgår et pædagogisk rationale for brugen af læringsteknologi, f.eks. med henblik på at motivere og/eller aktivere studerende. Her finder vi det særligt interessant, at man selv med en forholdsvis lille indsats kan påvirke studerendes faglige integration og i sidste ende mindske studerendes frafald. Dette så vi blandt andet eksemplificeret i afsnittet om motiverende kommunikation og kursusdesign, hvor direkte og opmuntrende kommunikation kan bidrage til både den faglige og sociale integration. Vi så også, hvordan anvendelsen af et digitalt afstemningsværktøj i forelæsninger kan inddrage de studerende direkte i undervisningen, bringe deres viden i spil og øge deres opmærksomhed. Vi har endvidere set, hvordan læringsteknologier kan anvendes til at give feedback, der løbende kan støtte tilegnelsen af et fags teori, empiri og metode. Eksemplerne illustrer samtidig, at studierne særligt fokuserer på den faglige integration i form af interaktion mellem underviser og studerende eller mellem studerende og stoffet og i mindre grad fokuserer på interaktion de studerende imellem. Hvorvidt frafald kan mindskes via et fokus på det sidste aspekt, giver studierne os ikke svar på.

Til trods for at studierne, der indgår i denne undersøgelse, primært er baseret på en amerikansk universitetskontekst, finder vi, at temaerne, som de beskæftiger sig med, er sammenfaldende med nogle af de temaer, som vi er optaget af i den danske uddannelsessektor og i en dansk universitetspædagogisk kontekst. For eksempel er aktiverende undervisning og aktiv læring de bærende principper for uddannelse på flere af de danske universiteter, herunder blandt andet Syddansk Universitet (Syddansk Universitet, 2018), IT-Universitetet (ITUniversitetet, 2019) og Roskilde Universitet (Roskilde Universitet, 2019). Endvidere beskriver danske studier af undervisningseksperimenter med læringsteknologi ofte undervisningsmetoder til aktivering af studerende - herunder de danske studier, som vi indledningsvist refererede til. Endelig anses adaptiv læring og automatiseret instruktion for at rumme så store potentialer for det danske uddannelsesmarked at Statens finansieringsfond, Vækstfonden, i 2018 skød 190 millioner kroner i udviklingen af adaptive læringsmoduler (Vækstfonden, 2018). Det kunne derfor være relevant at undersøge, om de nævnte temaer og konkrete strategier for undervisningsudvikling understøttet af læringsteknologi kan bidrage til at øge studerendes læring og motivation, og i forlængelse af dette bidrage til at reducere frafald i en dansk universitetskontekst.

Studierne savner generelt en beskrivelse af og kobling til kontekst- og studenterfaktorer, som vi ved fra anden forskning påvirker de studerendes engagement og faglige tilknytning (se f.eks. Biggs \& Tang, 2011; Ellis \& Goodyear, 2010; Entwistle, 2007; van Dinther, Dochy \& Segers, 2011). Endvidere savnes en kobling til den eksisterende forskning i online læring. Særligt amerikanske og canadiske forskere har beskæftiget sig med community of inquiry og 
undersøgt betydningen af underviserens tilstedeværelse online og sociale interaktioner (Garrison, Anderson \& Archer, 2010). Vi anbefaler derfor, at man i højere grad er opmærksom på den eksisterende forskning og kobler den til fremtidig forskning, der angår brugen af læringsteknologi til reduktion af frafald.

\section{Styrker og svagheder}

I denne undersøgelse har vi gennemført et systematisk review for at gennemgå resultaterne af international, peer-reviewed forskning, der undersøger brugen af læringsteknologi og sammenholder det med tal for frafald. Et systematisk review bør, hvis det er veludført, spare andre for at gennemføre lignende litteratursøgninger, henvise til interessante studier af høj kvalitet og præsentere en syntese af resultaterne inden for området (Bearman et al., 2012). 10 ud af 1.483 studier angik undersøgelsens fokus. I Appendix A har vi beskrevet samtlige kvalitetsvurderede studier for at give læseren mulighed for at vurdere denne undersøgelses kvalitet såvel som kvaliteten af de studier, der indgår i analysen. Vi har syntetiseret resultaterne af de studier, der levede op til etablerede standarder for forskningskvalitet (10/18). Vi har syntetiseret studierne, for at andre aktører inden for området så vidt muligt kan anvende resultaterne i egen undervisning eller strategi- og udviklingsarbejde. Det lave antal inkluderede studier giver dog anledning til at være forsigtig med at generalisere resultaterne. Tilsvarende skal man være forsigtig med at overføre resultaterne direkte til en dansk kontekst, da hovedparten af studierne i dette review er foretaget i en amerikansk universitetskontekst.

Ved hjælp af systematiske review er det muligt at kondensere en stor del af den viden, der findes inden for et felt. Undersøgelsen her er dog af flere grunde begrænset i forhold til at blotlægge alle undersøgelser af frafald inden for de videregående uddannelser, hvor læringsteknologi er blevet inddraget. Undersøgelsens søgestrategi er snæver. Den ekskluderer eksempelvis de studier, der ikke er identificeret ved hhv. frafald, læringsteknologi og 'higher education'. På samme vis er der ikke gennemført en supplerende screening af referencer, hvilket kunne have sikret identifikation af andre relevante studier. Selvom sprogrestriktioner ikke er ideelle, valgte vi i dette review at begrænse vores søgning til studier, der er publiceret i engelsksprogede peer-reviewede tidskrifter. Derved kan viden fra undersøgelser publiceret på dansk eller andre sprog være gået tabt. Undersøgelsen repræsenterer således kun et udsnit af forskningen inden for området, og der vil i fremtiden derfor være behov for undersøgelser, der anvender andre søgestrategier.

\section{Referencer}

Aarhus Universitet. (2018). Aarhus Universitet investerer i teknologisk udvikling af undervisningen. Hentet fra http://newsroom.au.dk/nyheder/vis/artikel/aarhusuniversitet-investerer-i-teknologisk-udvikling-af-undervisningen/

Aarhus Universitet, \& Uddannelses- og Forskningsministeriet. (2018). Strategisk rammekontrakt 2018-2021 Hentet fra https://www.ufm.dk/uddannelse/videregaendeuddannelse/universiteter/styring-og-ansvar/strategiskerammekontrakter/au strategisk-rammekontrakt-2018-21.pdf

Ashby, J., Sadera, W. A. \& McNary, S. W. (2011). Comparing student success between developmental math courses offered online, blended, and face-to-face. Journal of Interactive Online Learning, 10(3), 128-140. 
Bandura, A. (1993). Perceived self-efficacy in cognitive development and functioning. Educational psychologist, 28(2), 117-148.

Bearman, M., Smith, C. D., Carbone, A., Slade, S., Baik, C., Hughes-Warrington, M. \& Neumann, D. L. (2012). Systematic review methodology in higher education. Higher Education Research \& Development, 31(5), 625-640.

Bertel, T. F. \& Bentzen, T. Ø. (2018). Formativ evaluering med IT-systemet Peergrade. Tidsskriftet Loering og Medier (LOM), 10(18).

Biggs, J., \& Tang, C. (2011). Teaching for Quality Learning at University (4 ed.). Milton Keynes, UK: Open University Press.

Caviglia, F., Dalsgaard, C., Davidsen, J. \& Ryberg, T. (2018). Students' digital learning environments. Paper presented at the 11th International Networked Learning Conference.

Copenhagen Business School. (2017). The RiBL project is a 6-year externally funded project. Hentet fra http://blog.cbs.dk/ribl/the-ribl-project/

Danbjørg, D. B., Clemensen, J., Hansen, P. S., Thrysøe, L. \& Rothmann, M. J. (2018). BlogsLæringsfællesskab med rum til refleksion. Tidsskriftet Loring og Medier (LOM), 10(18).

Davidsen, J. \& Ryberg, T. (2016). Samhørighed, interaktion og vidensdeling blandt studerendeerfaringer fra et IKT-pædagogisk udviklingsprojekt. Dansk Universitetspcedagogisk Tidsskrift, 11(21), 57-71.

Dørup, J., Gomme, J., Hansen, A. \& Heiberg, B. (2005). Implementering af e-læring ved danske universiteter. Tidsskrift for Universiteternes Efter-og Videreuddannelse (UNEV), 3(6).

Dyrberg, N. R. (2014). Clickers-forbedring af traditionelle forelæsninger? MONA-Matematik-og Naturfagsdidaktik(2), 22-41.

Ellis, R. \& Goodyear, P. (2010). Students' experiences of e-learning in higher education: the ecology of sustainable innovation: Routledge.

Entwistle, N. (2007). Research into student learning and university teaching (Vol. 1): British Psychological Society.

Garratt-Reed, D., Roberts, L. D. \& Heritage, B. (2016). Grades, Student Satisfaction and Retention in Online and Face-to-Face Introductory Psychology Units: A Test of Equivalency Theory. Frontiers in Psychology, 7. doi:10.3389/fpsyg.2016.00673

Garrison, D. R., Anderson, T. \& Archer, W. (2010). The first decade of the community of inquiry framework: A retrospective. The internet and higher education, 13(1-2), 5-9.

Griff, E. R. \& Matter, S. F. (2013). Evaluation of an adaptive online learning system. British Journal of Educational Technology, 44(1), 170-176. doi:10.1111/j.14678535.2012.01300.x

Henderson, M., Selwyn, N. \& Aston, R. (2017). What works and why? Student perceptions of 'useful'digital technology in university teaching and learning. Studies in higher education, 42(8), 1567-1579. 
Henrie, C. R., Halverson, L. R. \& Graham, C. R. (2015). Measuring student engagement in technology-mediated learning: A review. Computers \& Education, 90, 36-53.

Hughes, G. (2007). Using Blended Learning to Increase Learner Support and Improve Retention. Teaching in Higher Education, 12(3), 349-363.

Inkelaar, T. \& Simpson, O. (2015). Challenging the 'distance education deficit' through 'motivational emails'. Open Learning, 30(2), 152-163. doi:10.1080/02680513.2015.1055718

IT-Universitetet. (2019). Pædagogiske Principper på IT-Universitetet i København. Hentet fra https://www.itu.dk/om-itu/paedagogiske-principper

Jensen, M. B., Lindorf, M., Norn, M. T. \& Aller, S. H. (2015). Styrk uddannelseskvaliteten gennem digitale loeringsteknologier. Hentet fra https://dea.nu/sites/dea.nu/files/dea styrk uddannelseskvaliteten gennem digitale laeringsteknologier.pdf

Littell, J. H., Corcoran, J. \& Pillai, V. (2008). Systematic reviews and meta-analysis: Oxford University Press.

Liu, W. C. \& Stengel, D. N. (2011). Improving Student Retention and Performance in Quantitative Courses Using Clickers. International Journal for Technology in Mathematics Education, 18(1), 51-58.

Mager, U. \& Nowak, P. (2012). Effects of student participation in decision making at school. A systematic review and synthesis of empirical research. Educational research review, $7(1), 38-61$.

Means, B., Toyama, Y., Murphy, R., Bakia, M. \& Jones, K. (2010). Evaluation of Evidence-Based Practices in Online Learning. A Meta-Analysis and Review of Online Learning Studies Hentet fra https://www2.ed.gov/rschstat/eval/tech/evidence-basedpractices/finalreport.pdf

Møller, R. B. (2016). Introduktion til diskussionsforum som læringsplatform. Dansk Universitetspoedagogisk Tidsskrift, 11(21), 158-165.

Online Learning Consortium. (2015). Updated E-Learning Definitions. Hentet fra https://onlinelearningconsortium.org/updated-e-learning-definitions-2

Pittenger, A. \& Doering, A. (2010). Influence of motivational design on completion rates in online self-study pharmacy-content courses. Distance Education, 31(3), 275-293. doi:10.1080/01587919.2010.513953

Powers, K. L., Brooks, P. J., Galazyn, M. \& Donnelly, S. (2015). Testing the Efficacy of MyPsychLab to Replace Traditional Instruction in a Hybrid Course. Psychology Learning and Teaching, 15(1), 6-30. doi:10.1177/1475725716636514

Price, L. \& Kirkwood, A. (2011). Enhancing learning and teaching through technology. York, UK: Higher Education Academy.

Robb, C. A. \& Sutton, J. (2014). The importance of social presence and motivation in distance learning. Journal of Technology, Management, and Applied Engineering, 31(2), 1-10. 
Roskilde Universitet. (2017). RUC får 20 mio. til virtuelle læringsteknologier. Hentet fra https://ruc.dk/nyheder/ruc-far-20-mio-til-virtuelle-laeringsteknologier

Roskilde Universitet. (2019). Pædagogisk profil på Roskilde Universitet. Hentet fra https://intra.ruc.dk/fileadmin/assets/adm/dokumenter og noegletal/vaerdier/Paedag ogisk_profil_DK.pdf

Savin-Baden, M. \& Major, C. H. (2010). New approaches to qualitative research: Wisdom and uncertainty: Routledge.

Styrelsen for Forskning og Uddannelse. (2018). Frafald og studieskift. Spørgeskemaundersøgelse blandt frafaldne studerende ved videregående uddannelser. Hentet fra København: https://ufm.dk/publikationer/2018/filer/frafald-og-studieskift.pdf

Syddansk Universitet. (2018). Bærende principper. Retrieved from https://www.sdu.dk/da/om sdu/institutter centre/c unipaedagogik/baerende princip per

Syddansk Universitet, \& Uddannelses- og Forskningsministeriet. (2018). Strategisk rammekontrakt 2018-2021. Hentet fra https://ufm.dk/uddannelse/videregaendeuddannelse/universiteter/styring-og-ansvar/strategiskerammekontrakter/sdu strategisk-rammekontrakt-2018-21.pdf

Tinto, V. (1975). Dropout from higher education: A theoretical synthesis of recent research. Review of educational research, 45(1), 89-125.

Tong, A., Sainsbury, P. \& Craig, J. (2007). Consolidated criteria for reporting qualitative research (COREQ): a 32-item checklist for interviews and focus groups. International journal for quality in health care, 19(6), 349-357.

Troelsen, R. (2011). Frafald på de videregående uddannelser-hvad ved vi om årsagerne? Dansk Universitetspoedagogisk Tidsskrift, 6(10), 37-44.

Uddannelses- og Forskningsministeriet. (2018). Frafald. Tal, analyser og undersøgelser om frafald på videregående uddannelser, som løbende bliver udarbejdet af ministeriet. Hentet fra https://ufm.dk/uddannelse/statistik-og-analyser/frafald

Ulriksen, L., Madsen, L. M. \& Holmegaard, H. T. (2010). What do we know about explanations for drop out/opt out among young people from STM higher education programmes? Studies in Science Education, 46(2), 209.

Vækstfonden. (2018). Ny investering: Area9 kan blive fyrtårn inden for uddannelsesteknologi. Hentet fra https://www.vf.dk/nyheder-og-analyser/nyheder/2018/20180110-area9faar-investering.aspx

van Dinther, M., Dochy, F. \& Segers, M. (2011). Factors affecting students' self-efficacy in higher education. Educational research review, 6(2), 95-108.

Willis, R., Yeigh, T., Lynch, D., Smith, R., Provost, S., Sell, K. \& Turner, D. (2017). Towards a Strategic Blend in Education: A review of the blended learning literature: Lulu. com.

Wladis, C., Conway, K. \& Hachey, A. C. (2017). Using course-level factors as predictors of online course outcomes: a multi-level analysis at a US urban community college. Studies in higher education, 42(1), 184-200. doi:10.1080/03075079.2015.1045478 
Xu, D. \& Jaggars, S. S. (2011). The Effectiveness of Distance Education across Virginia's Community Colleges: Evidence from Introductory College-Level Math and English Courses. Educational Evaluation and Policy Analysis, 33(3), 360-377. 